\title{
Selenium and Mercury Toxicity: The Tale of Fish ${ }^{1}$
}

Razieh Farzad and Jeanette Andrade ${ }^{2}$

This document is the first in a "Fish and Human Nutrition" series, which seeks to help consumers make a knowledgebased decision when choosing their seafood.

\section{Introduction}

Fish is an essential component of a well-balanced diet. Not only is fish a good source of protein, but it also provides essential fatty acids such as omega-3, vitamins such as vitamin $\mathrm{D}$, and minerals such as selenium (Se) (Khalili Tilami and Sampels 2017). The American Heart Association (AHA) recommends eating at least two servings ( 3.5 oz) of nonfried fatty fish (e.g., salmon or sardines) weekly for health. However, consumers are concerned about exposure to mercury through fish consumption. The degree of exposure to mercury depends on both the amount and the type of fish consumed. Additionally, recent studies have shown that Se can prevent mercury poisoning (Berry and Ralston 2008). To better understand the risk of mercury exposure through seafood consumption, understanding selenium-mercury interaction is useful.

\section{What is selenium (Se)?}

Selenium is an essential trace mineral, which means it comes from foods consumed but is only needed in small amounts. Foods that contain Se include grains, red meat, poultry, and fish (National Institutes of Health 2021), with higher Se content found in fish. The Recommended Dietary Allowance for Se is 55 micrograms $(\mu \mathrm{g})$ for adults older than 18 years. Selenium is a powerful antioxidant that may reduce cancer risk, and it is essential for thyroid function and the immune system (Tapiero et al. 2003).

Severe Se deficiency (intake $<20 \mu \mathrm{g}$ per day) has adverse health effects and was initially associated with fatal heart disease (Li et al. 1985). It is now known that Se deficiency is linked to multiple neurological disorders, such as congenital muscular dystrophy, autism, Alzheimer's disease, and brain tumors, and to other chronic conditions, such as diabetes and liver diseases (Coppinger and Diamond 2001). In addition, conditions associated with increased oxidative stress or inflammation, such as rheumatoid arthritis, pancreatitis, asthma, and even obesity, are linked to Se deficiency (Roy et al. 1995; Ramauge et al. 1996; Behne et al. 2000; Combs and Lu 2001).

\section{How does Se help detoxify mercury?}

Mercury exists in fish due to natural processes and human activity. Methylmercury has an adverse effect on the central nervous system, particularly the developing brain of a fetus. Mercury has a strong binding affinity for Se and acts as a Se magnet that produces a mercury-selenium substance that is not absorbable in the human body (Ralston et al. 2016). As a result of this new compound, the mercury will be removed from the body before it is deposited in fatty tissue and causes damage. Because this mercury-selenium interaction effectively prevents mercury absorption, scientists are modifying the concept of mercury toxicity (Ralston et

1. This publication is FSHN22-4, one of a series of the Food Science and Human Nutrition Department, UF/IFAS Extension. Original publication date February 2022. Visit the EDIS website at https://edis.ifas.ufl.edu/ for the currently supported version of this publication.

2. Razieh Farzad, assistant professor and seafood safety Extension specialist, Food Science and Human Nutrition Department and Florida Sea Grant; and Jeanette Andrade, assistant professor and director, MS-DI program, Food Science and Human Nutrition Department; UF/IFAS Extension, Gainesville, FL 32611.

The Institute of Food and Agricultural Sciences (IFAS) is an Equal Opportunity Institution authorized to provide research, educational information and other services

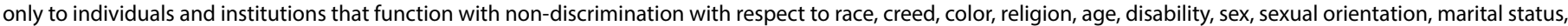

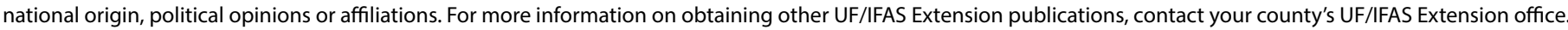
U.S. Department of Agriculture, UF/IFAS Extension Service, University of Florida, IFAS, Florida A \& M University Cooperative Extension Program, and Boards of County Commissioners Cooperating. Andra Johnson, dean for UF/IFAS Extension. 
al. 2016). To efficiently bind to mercury and produce the Se-containing antioxidant compounds that benefit us, it is critical that we maintain an adequate level of Se in our body, which can be achieved by a diet rich in Se.

\section{Can Se help minimize the risk of mercury exposure from fish consumption?}

Fish and seafood are good sources of the long-chain, omega-3 polyunsaturated fatty acids DHA (docosahexaenoic acid) and EPA (eicosapentaenoic acid) (Khalili Tilami and Sampels 2017). It is essential to understand the real risk of avoiding fish versus the potential risk of methylmercury exposure from eating fish. EPA and DHA are vital for neurological development during the early years of life and are believed to benefit cardiovascular health (Kris-Etheron and Harris 2002). Ocean fish are an excellent source of Se (Table 1), and the overall risk of consuming mercury can be minimal. Dietary sources of Se, particularly seleniumrich fish, minimize the risk of mercury exposure. One of the few studies that showed evidence of the detrimental effects of eating seafood was associated with maternal consumption of pilot whale. This marine mammal contains more mercury than Se (George et al. 2011). In addition, epidemiological studies have highlighted the positive effects of fish consumption during pregnancy. Children whose mothers consumed at least 21 ounces of fish per week during pregnancy demonstrated higher neurocognitive function compared to children whose mothers did not consume fish during pregnancy (Davidson et al. 1998; Myers and Davidson 1998; Hibbeln et al. 2007; Oken et al. 2008; Lederman et al. 2008).

Table 1. Selenium Health Benefit Value of various fish species (Farzad et al. 2019; Ralston et al. 2019). Positive HBV means that fish are safe regarding mercury toxicity.

\begin{tabular}{|l|c|}
\hline \multicolumn{1}{|c|}{ Fish Species } & Health Benefit Value of Se \\
\hline Nile tilapia & 11.83 \\
\hline Beigey tuna & 11.47 \\
\hline Skipjack tuna & 19.61 \\
\hline Swordfish & 0.28 \\
\hline Mako shark & -16.44 \\
\hline Pilot whale & -14.79 \\
\hline
\end{tabular}

Se and mercury interaction is complex and depends on various factors, such as the forms of Se and mercury, relative amounts of each, and the organ in which they are interacting (Spiller 2017). An index called the Se Health Benefit Value (HBV) has been developed to assess the mercury risk associated with various types of fish. A positive $\mathrm{HBV}$ value means that the fish has a higher concentration of Se than mercury, and it is safe to eat because all the mercury will be offset by Se. A negative HBV value means that the mercury concentration exceeds the Se concentration, and consumption of the fish may result in mercury exposure. The HBV index is conservative and does not account for other dietary Se sources or Se reserves already present in the body (Ralston et al. 2016; Ralston et al. 2019). Table 2 shows the HBV of Se available for some freshwater and marine fish. It is important to note that despite their positive HBV values, some types of fish with relatively high mercury content, such as swordfish and bigeye tuna, are considered inappropriate choices for children and pregnant/lactating mothers.

Table 2. EPA-FDA advice regarding fish consumption for pregnant and nursing women, women of childbearing age, and people who prepare food for young children (FDA 2020).

\begin{tabular}{|c|c|}
\hline $\begin{array}{l}\text { Best Choices } \\
\text { Eat } 2 \text { to } 3 \text { servings a week } \\
\text { Adult serving }=4 \text { oz; } \\
\text { Children's serving (aged } \\
4-7 \text { years) }=2 \mathrm{oz}\end{array}$ & $\begin{array}{l}\text { Anchovy, Atlantic croaker, Atlantic } \\
\text { mackerel, Black sea bass, Butterfish, } \\
\text { Catfish, Clam, Cod, Crab, Crawfish, } \\
\text { Flounder, Haddock, Hake, Herring, } \\
\text { Lobster (American and spiny), Mullet, } \\
\text { Oysters, Pacific chub mackerel, Perch } \\
\text { (freshwater and ocean), Pickerel, } \\
\text { Plaice, Pollock, Salmon, Sardines, } \\
\text { Scallops, Shad, Shrimp, Skate, Smelt, } \\
\text { Sole, Squid, Tilapia, Trout (freshwater), } \\
\text { Tuna (canned light), Whitefish, Whiting }\end{array}$ \\
\hline $\begin{array}{l}\text { Good Choices } \\
\text { Eat } 1 \text { serving a week } \\
\text { Adult serving = } 4 \text { oz; } \\
\text { Children's serving (aged } \\
4-7 \text { years) }=2 \mathrm{oz}\end{array}$ & $\begin{array}{l}\text { Bluefish, Buffalo fish, Carp, Chilean sea } \\
\text { bass/Patagonian toothfish, Grouper, } \\
\text { Halibut, Mahi-mahi/dolphinfish, } \\
\text { Monkfish, Sablefish, Sheepshead, } \\
\text { Snapper, Spanish mackerel, Striped } \\
\text { bass (ocean), Tilefish (Atlantic Ocean), } \\
\text { Tuna (albacore/white tuna, canned } \\
\text { and frozen), Tuna (yellowfin), White } \\
\text { croaker/Pacific croaker }\end{array}$ \\
\hline
\end{tabular}

Choices to Avoid Highest mercury level King mackerel, Marlin, Orange roughy, Shark, Swordfish, Tilefish (Gulf of Mexico), Tuna (bigeye)

\section{How much fish should we eat to reduce mercury toxicity?}

The current federal advisory for fish consumption does not account for the Se-mercury interaction. The Food and Drug Administration (FDA), in coordination with the Environmental Protection Agency (EPA), has an advisory for fish and methylmercury called "Advice about Eating Fish" (FDA 2021). This document contains the consumption advice on specific amounts and types of fish to improve health and developmental outcomes while minimizing risk from methylmercury for pregnant and nursing women, women of childbearing age, and anyone who prepares food for young children. Fish species vary in the extent to which they pose a risk of methylmercury exposure to the consumer. The FDA and EPA advisory document categorize 
fish species into consumption frequencies (Table 1) linked to recommendations that minimize the risk for such exposure while encouraging fish consumption.

For an adult, 1 serving = 4 ounces, and the EPA-FDA recommendation is to eat 2 to 3 servings a week from the "Best Choices" list (or 1 serving from the "Good Choices" list). For children, a serving is 1 ounce at age 2, increasing to 4 ounces by age 11 .

If you are eating fish that are caught by family and friends in local lakes, rivers, and coastal areas, check the local advisory about the safety of those fish. To find advice about eating fish from Florida waters, you can check the Florida Department of Health Fish Advisory.

\section{References}

Behne, D., H. Pfeifer, D. Rothlein, and A. Kyriakopoulos. 2000. "Cellular and Subcellular Distribution of Selenium and Selenium-Containing Proteins in the Rat." In Trace Elements in Man and Animals 10, edited by A. M. Roussel, A. E. Favier, and R. A. Anderson, 29-34. New York: Kluwer Academic/Plenum Publishers. https://doi. org/10.1007/0-306-47466-2_5

Berry, M. J., and N. V. Ralston. 2008. "Mercury Toxicity and the Mitigating Role of Selenium." Ecohealth 5 (4): 456-459. https://doi.org/10.1007/s10393-008-0204-y

Combs Jr., G. F., and Lu, J., 2001. “Selenium as a Cancer Preventive Agent." In Selenium, edited by D. L. Hatfield, 205-217. Hingham, ME: Kluwer Academic Publishers.

Coppinger, R. J., and A. M. Diamond. 2001. "Selenium Deficiency and Human Disease." In Selenium: Its Molecular Biology and Role in Human Health, edited by Dolph L. Hatfield, 219-233. Boston: Springer US.

Davidson, P. W., G. J. Myers, C. Cox, C. Axtell, C. Shamlaye, J. Sloane-Reeves, E. Cernichiari, L. Needham, A. Choi, Y. Wang, M. Berlin, and T. W. Clarkson. 1998. "Effects of Prenatal and Postnatal Methylmercury Exposure from Fish Consumption on Neurodevelopment: Outcomes at 66 Months of Age in the Seychelles Child Development Study." JAMA 280 (8): 701-707. https://doi.org/10.1001/ jama.280.8.701

Farzad, R., D. D. Kuhn, S. A. Smith, S. F. O’Keefe, N. V. C. Ralston, A. P. Neilson, and D. M. Gatlin. 2019. "Trace Minerals in Tilapia Fillets: Status in the United States Marketplace and Selenium Supplementation Strategy for
Improving Consumer's Health." PLoS One 14 (6): e0217043. https://doi.org/10.1371/journal.pone.0217043

FDA. 2021. "Advice about Eating Fish." https://www.fda. gov/food/consumers/advice-about-eating-fish

George, G. N., T. C. MacDonald, M. Korbas, S. P. Singh, G. J. Myers, G. E. Watson, J. L. O’Donoghue, and I. J. Pickering. 2011. "The Chemical Forms of Mercury and Selenium in Whale Skeletal Muscle." Metallomics 3 (11): 1232-1237. https://doi.org/10.1039/c1mt00077b

Grandjean, P., P. Weine, R. F. White, F. Debes, S. Araki, K. Yokoyama, K. Murata, N. Sørensen, R. Dahl, and P. J. Jørgensen. 1997. "Cognitive Deficit in 7-Year-Old Children with Prenatal Exposure to Methylmercury." Neurotoxicol Teratol. 19 (6): 417-28. https://doi.org/10.1016/ s0892-0362(97)00097-4

Hibbeln, J. R., J. M. Davis, C. Steer, P. Emmett, I. Rogers, C. Williams, and J. Golding. 2007. "Maternal Seafood Consumption in Pregnancy and Neurodevelopmental Outcomes in Childhood (ALSPAC Study): An Observational Cohort Study." Lancet 369 (9561): 578-585. https:// doi.org/10.1016/S0140-6736(07)60277-3

Kaneko, J. J., and N. Ralston. 2007. "Selenium and Mercury in Pelagic Fish in the Central North Pacific near Hawaii." Biol Trace Elem Res 119 (3): 242-254. https://doi. org/10.1007/s12011-007-8004-8

Khalili Tilami, S., and S. Sampels. 2018. "Nutritional Value of Fish: Lipids, Proteins, Vitamins, and Minerals." Rev Fish Sci Aquac 26 (2): 243-53. https://doi.org/10.1080/23308249 .2017 .1399104

Kris-Etherton, P. M., W. S. Harris, and L. J. Appel. 2002. "Fish Consumption, Fish Oil, Omega-3 Fatty Acids, and Cardiovascular Disease." Circulation 106 (21): 2747-57. https://doi.org/10.1161/01.cir.0000038493.65177.94

Li, G. S., F. Wang, D. Kang, and C. Li. 1985. "Keshan Disease: An Endemic Cardiomyopathy in China." Hum Pathol 16 (6): 602-9. https://doi.org/10.1016/ s0046-8177(85)80110-6

Myers, G. J., and P. W. Davidson. 1998. "Prenatal Methylmercury Exposure and Children: Neurologic, Developmental, and Behavioral Research." Environ. Health Perspect. 106 (suppl 3): 841-847. https://doi.org/10.1289/ehp.98106841 
National Institutes of Health (NIH). 2021. "Selenium: Fact Sheet for Health Professionals." https://ods.od.nih.gov/ factsheets/Selenium-HealthProfessional/

Oken, E., M. L. Østerdal, M. W. Gillman, V. K. Knudsen, T. I. Halldorsson, M. Strøm, D. C. Bellinger, M. HaddersAlgra, K. Fleischer-Michaelsen, and S. F. Olsen. 2008. "Associations of Maternal Fish Intake during Pregnancy and Breastfeeding Duration with Attainment of Developmental Milestones in Early Childhood: A Study from the Danish National Birth Cohort." Am. J. Clin. Nutr. 88 (3): 789-796. https://doi.org/10.1093/ajcn/88.3.789

Ralston, N. V. C., J. J. Kaneko, and L. J. Raymond. 2019. "Selenium Health Benefit Value Provide a Reliable Index of Seafood Benefits vs. Risks." J Trace Elem Med Biol. 55:50-57. https://doi.org/10.1016/j.jtemb.2019.05.009

Ralston, N. V. C., R. Ralston, and L. J. Raymond. 2016. "Selenium Health Benefit Values: Updated Criteria for Mercury Risk Assessments." Biol Trace Elem Res 171 (2): 262-9. https://doi.org/10.1007/s12011-015-0516-Z

Ramauge, M., S. Pallud, A. Esfandiari, J. M. Gavaret, A. M. Lennon, M. Pierre, and F. Courtin. 1996. "Evidence That Type III Iodothyronine Deiodinase in Rat Astrocyte Is a Selenoprotein." Endocrinology 137 (7): 3021-3025. https:// doi.org/10.1210/en.137.7.3021

Roy, M., L. Kiremidjian-Schumacher, H. I. Wishe, M. W. Cohen, and G. Stotzky. 1995. "Supplementation with Selenium Restores Age-Related Decline in Immune Cell." Proc Soc Exp Bio Med 209 (4): 369-75. https://doi. org/10.3181/00379727-209-43909

Spiller, H. A. 2017. "Rethinking Mercury: The Role of Selenium in Pathophysiology of Mercury Toxicity." J. Clin Toxicol 56 (5): 313-326. https://doi.org/10.1080/15563650.2 017.1400555

Tapiero, H., D. M. Townsend, and K. D. Tew. 2003. "The Oxidant Role of Selenium and Seleno-Compound." Biomed Pharmacother. 57 (3-4): 134-144. PNCID: PMC6361120

USDA and US Department of Health and Human Services. 2020. Dietary Guidelines for Americans, 2020-2025. 9th Edition. https://www.dietaryguidelines.gov/ resources/2020-2025-dietary-guidelines-online-materials 